\title{
Out of Bounds: The Spatial Politics of Civility in The Square (Östlund, 2017) and Happy End (Haneke, 2017)
}

\author{
Elizabeth Ezra
}

There are different ways of interpreting the movement that defines immigration: as cultural enrichment or as intrusion (or indeed, as the most highly charged political rhetoric would have it, as 'invasion'). Immigrants themselves are alternatively objects of hostility or recipients of hospitality-and often both at the same time. Civility, or the extension of respect and consideration to an other or others, is rooted in citizenship, which itself has its roots in the city. Immigrants enter the city perceived as either intruders or guests, a determination dependent on the vicissitudes of perspective, whether in terms of location or locution.

In 2017, two films were released that examine the intersection of these terms: The Square, a Swedish film directed by Ruben Östlund, and Happy End, a French-language film made by Austrian director Michael Haneke. At the time these films were made, Britain had just voted to leave the European Union, and Donald Trump had just been elected President of the United States, events connected not only by shared actors and the role of extranational influences in both outcomes, but also by the antipathy towards immigrants that both campaigns successfully exploited. The growing presence of populist far-right movements across Europe and the U.S., as well as the rise of anti-Semitism and Islamophobia in both places, provide further context for understanding the relationship between civility and citizenship in these films. Both The Square and Happy End examine the construction of social space as a bounded zone with insiders and outsiders. These films show the breaching of these boundaries, often by insiders who express outrage on behalf of outsiders. They also show how the accrual of debt has the potential to turn spaces of hospitality into places of confrontation and violence. 


\section{The Square}

In The Square, set in the rarefied world of the international art scene, the director of a modern art museum in Stockholm (played by Claes Bang) has his wallet and phone stolen, and sends an anonymous letter to the occupants of each apartment in a low-income housing block accusing them of the theft. A recipient of one of these letters, a pre-adolescent immigrant boy who is not named, confronts the museum director, named Christian, and threatens to 'cause chaos' for him if he does not apologize to the boy's family. Meanwhile, Christian is overseeing the installation of an exhibit called 'The Square', which consists only of a white square drawn on the cobblestones in the courtyard in front of the museum, and an accompanying plaque with the words: 'The Square is a sanctuary of trust and caring. Within its boundaries, we all share equal rights and obligations.' Near the beginning of the film, we see a statue of a military commander, complete with Napoleonic bicorne, being lowered from a plinth in the museum's courtyard; the crane loses hold of the statue, which is decapitated as it falls unceremoniously to the ground. In the background, a banner announces the name of the museum: X-Royal, suggesting a literal toppling of monarchy. The statue seems to have been removed in order to make way for 'the square', invoking the possibility (perhaps in general, not literal terms) of an evolution from a system of inherent inequality to a more egalitarian society.

The film underscores the hypocrisy of the exhibit's emphasis on trust and caring in relation to Christian's own life, but it also shows him grappling with the implications of the piece. The artwork that gives its name to The Square invites people to cross its borders, but by inviting people 'in', it necessarily establishes the boundary between 'inside' and 'out'. The spatial dimension of this distinction is important with regard to immigration, which, again, is about the movement from 'there' to 'here', but it also applies to art itself. 'The Square' itself is a work of art, but its physical resemblance to a frame raises the question of exhibition, and of context, both of which determine the status of art as such.

The importance of context and location to art, and to conceptual art in particular, is invoked in a scene in which an exhibit at the museum, entitled 'Rocks and Piles of Gravel', is damaged when a cleaner accidentally vacuums 
some of it up, and Christian instructs an employee to recreate the missing section of the exhibit. By means of their placement in a gallery, the piles of gravel are granted the status of art; it does not matter who fashions those piles, the film is suggesting ironically, as long as they exist in a space reserved for the exhibition of art. Christian reinforces this idea in an interview with an American journalist, Anne (Elisabeth Moss) when he explains that if he took her handbag and moved it from 'here' (i.e., in close proximity to her) to 'there' (away from her, in the museum's exhibition space), the bag could become a work of art. This example not only links art to location; in evoking the removal and displacement of Anne's handbag, and therefore, presumably, her wallet and phone, it foreshadows the scene in which Christian's wallet and phone are taken from him. Theft, too, is the displacement of something from 'here' to 'there', from one's possession to that of another.

The question of property, of belongings, is linked in the film to the question of propriety, and of belonging. A neon sign saying 'You have nothing' is visible behind Christian during his interview with Anne. It is a work of art because it is on display in a museum, but its message resonates beyond this context, invoking the distinctions of social class that separate the 'haves' from the 'have-nots'. The international art world is clearly a world of the haves, so the sign is not really speaking to them-unless it is speaking metaphorically, about, say, moral or spiritual values. The 'have-nots', who are largely absent from the museum space, inhabit the housing estate whose low-income and mostly immigrant occupants Christian accuses of stealing his belongings. The sentence 'You have nothing' includes a deictic, a word whose meaning changes according to the position of the speaker (e.g., 'here' and 'there', but also 'I' and 'you'). The same deictic is used later in the film, when Christian brings his two young daughters to the museum to see a new exhibition in which visitors are asked to press one of two buttons on a console emblazoned with the words 'Who are you?' Indeed, who is 'you'? Is it possible that, to paraphrase Rimbaud, you is an other? Is the implied 'you' of 'Who are you?' the same as the implied 'you' of 'You have nothing'? In the question 'Who are you?', the implied addressee is a middle-class museum-goer. In the statement 'You have nothing', the implied addressee is an indigent person if the statement is taken literally, or the same middle-class museum-goer if the 
statement is interpreted in a spiritual or ethical sense. Interpreting the statement metaphorically, museum-goers and viewers of the film acknowledge their ideological interpellation into the world of middle-class guilt (something that could apply to Östlund's work itself, which often not only depicts, but also seems to be aimed at white Swedish middle classes).

The word 'who' in the question 'Who are you?' is also asking visitors to determine their ethical position in relation to other people. The two buttons on the console read, respectively, 'I mistrust people' and 'I trust people', both sentences using another deictic, 'I'. The museum exhibit comprises a room with two entrances. 'To enter', Christian tells his daughters, 'you have to decide whether you trust other people, or that you don't, you mistrust them. This is done by pushing the appropriate button'. Both girls press 'I trust people'. When they enter through the door they have chosen, they hear monkey sounds, and they are instructed to leave their wallets and phones on the floor. Christian accompanies the girls into the 'trusting' space, which is ironic, considering that he did not display much trust in people when he slipped a note through the mail slots of every apartment in a low-income tower block accusing the occupants indiscriminately of robbing him. He also is notably mistrustful of Anne when he refuses to relinquish the condom they have used during their sexual encounter. Anne wants the condom to go 'there' in the wastepaper basket, but Christian wants it to go 'here' with him. He appears to be afraid that Anne will use his sperm to impregnate herself. He does not want to give up something he feels is 'his'-in this instance, not only the condom, but also his DNA. He may also be thinking about the circumstances of his mugging, when a woman reached into his pocket and stole his phone and wallet, and he may not want to surrender anything of his to a woman again. Anne wins the battle-she gets the condombut she seems to lose the war, as Christian becomes distant and neglects to respond to her requests for more contact.

The question of trust is linked to the question of 'here' and 'there', and therefore, 'us' and 'them'. While 'here', a person is a citizen, but once that citizen moves from 'here' to 'there', he or she becomes an immigrant. It is significant, in this context, that the video made to promote the exhibit 'The Square' features a blonde child, whose hair colour is specified repeatedly (as 'fair') in the pitch 
made by the marketing firm to the museum administrators. The person who represents the object of kindness and tolerance in the space of the square is explicitly not an immigrant, but a native Swede (in the pitch, the marketing executives expressly state that the child should have fair hair in order to 'represent the Swedish'). Or perhaps she is like Christian, an immigrant from Denmark, or like the equally blonde Anne, a visitor (or possibly an immigrant) from North America-neither of whom speaks Swedish in the film. The suggestion is that the little girl is not an immigrant, but a native Swede. The implication is that showing a native Swede being blown up will elicit more outrage than if the child were thought to be an immigrant. Perhaps the film is suggesting that there are immigrants and there are immigrants. The boy who causes 'chaos' for Christian has, as Christian describes him when looking for him, 'pitch black hair', and the neighbour he asks about him describes him as having 'really dark hair' - unlike the blond hair of the child in the video. Although the subject of immigration is tangential to the plot of The Square, it nonetheless haunts the film at almost every turn.

The Square was released in 2017. In 2015, a record-breaking 162,877 asylum seekers entered Sweden, primarily from Syria and Afghanistan. In response, Sweden introduced new border controls at the beginning of 2016, followed by a 'highly restrictive asylum and reunification law' later that year (Skodo 2018: $n p$ ). This new approach to immigration challenged the country's roughly 90-year political tradition of folkhemmet (translated as 'the people's home'), announced in Democratic Party Leader Per Albin Hansson's renowned speech in 1928, in which, as Kate Moffat notes, 'he outlined the basic tenets of universal equality and inclusivity. The term was designed, above all, to encapsulate a vision of collective social and cultural cohesion. On the surface, folkhemmet promised equality to all citizens through a comprehensive statesubsidized social welfare programme ... underpinned by an implicit contrast between native Swedes and those who did not belong or conform to the ideals and practices endorsed by the state' (Moffat 2019: 38). By appealing to viewers' sense of what is out of bounds, The Square stages confrontations between those who appear to 'belong' and those who do not, inviting contemplation of the very notion of belonging. 
The Square might be best described as a film about infraction, or interruption, both of which are, etymologically, break-ins. From the fussing baby in the board room during a marketing meeting to the very loud sounds in the gallery when Anne is confronting Christian, to the man with Tourette's Syndrome interrupting an artist's interview, there is a lot of intrusion. When we first learn that Christian has children, it is because they have burst into his apartment; at first, he thinks they are an intruder. They come bounding into the flat, shouting and fighting with each other, bringing the 'chaos' into his life that the menacing letter threatens. He then loses his cool and shouts uncontrollably at the kids (which, while not a particularly unusual parental response, nonetheless seems relatively out of character for Christian).

The most arresting example of 'going out of bounds' is the notorious scene set at a fundraising dinner. Here, an artist (played by Terry Notary, known for playing animals and non-human creatures, and especially for his work in Tim Burton's 2001 Planet of the Apes remake) has been hired to lumber around the room making monkey noises while standing on the dining tables. The performance goes far beyond the bounds of polite society when the ape-artist attacks a woman, pulling her by the hair and straddling her as if to rape her, and first one man and then a number of men attending the dinner beat him up. A space of hospitality has turned into a place of hostility.

The artist's masquerade as an ape evokes the status of animality in the film, and recalls the monkey (or ape) sounds emanating from the exhibition about trusting people described above. Moreover, two scenes in the film show an actual ape, who appears to live with Anne in her apartment. The first time we see the ape, s/he is drawing with a coloured pen on an artist's sketch pad, exhibiting one of the defining characteristics of humanity: the capacity to create art. The next time we see the ape-when Anne is phoning Christian to ask why he has not returned her calls - the ape is sitting on the bed next to Anne, drawing on his/her lips with a coloured pen. The ape as artist is an inversion of the artist-asape, and mirrors (or 'apes') Anne's attempts to maintain Christian's sexual interest in her. The presence of apes in these scenes adds to the film's satirical critique of the international art scene, invoking the proverbial monkeys-withtypewriters randomly composing great works of art-but it also raises the 
question of who gets recognized as human, that is, not only civilised, but also worthy of recognition.

Scenes like the one set at the fundraising dinner are disturbing because they illustrate an intrusion into both a physical and social space thought to protect its occupants. Like the 'people's home', and like 'The Square' exhibit, the gala dinner is a safe space, designed to be free from the threatening intrusions of the outside world. It is all the more shocking, then, when the social boundaries marked by these spaces are breached: a woman is attacked at the fundraising dinner, and a child is blown up in the ad for 'The Square'. Both of these breaches are intended to attract the attention of the media and thus of potential museum visitors. Through these promotional events, the museum is suggesting that safe spaces that are not breached are boring, and not worthy of attention. Only infraction, intrusion, is worthy of attention in what Jonathan Beller (2012) calls the 'attention economy'. The ad itself is deemed out of bounds, and yet, it is a success, in that it achieves the desired effect of attracting free media coverage and drawing visitors to the exhibition. Because it is profitable within the attention economy, it stretches the boundaries of acceptability so that its tactics are ultimately accepted. Thinking outside the box results in a bigger box within which formerly unacceptable thoughts becomes acceptable.

\section{Happy End}

Like The Square, Michael Haneke's Happy End appears to place immigration at the margins, rather than at the centre, of its narrative, but in fact, features climactic scenes of intrusion that invite viewers to think about immigration in the context of the complex relationship between hospitality and hostility. Happy End is set in Calais, home of the infamous migrant camp known as the Jungle. French authorities dismantled the camp in November of 2016, but migrants and asylum-seekers have continued to live in the area ever since. The film revolves around a wealthy family who owns a construction company: the patriarch, named Georges Laurent (Jean-Louis Trintignant), his daughter Anne (Isabelle Huppert), who runs the company with her son Pierre (Franz Rogowski), and 
Anne's brother Thomas (Mathieu Kassovitz), a doctor, who is raising his daughter Eve with his second wife. Regular viewers of Haneke's films will notice that the names Georges and Anne Laurent are used repeatedly throughout the director's oeuvre and across a range of very different characters, endowing the characters in this film with the somewhat deceptive appearance of familiarity. When an accident on the family construction site results in a worker casualty, familial and other emotional bonds are tested, as the boundaries between hosts and guests are held up to scrutiny. The intersection between these two dynamics - the retrenchment into one's own tribe on the one hand and the breaking down of borders on the other-is represented by the film's recurring motif of intrusion.

The theme of intrusion is flagged up at the beginning of the film, which opens with a woman being observed by a camera, apparently without her knowledge, as she prepares for bed. The viewer, who watches the woman through the camera lens, is immediately put in the position of a voyeur or intruder, watching her perform her ablutions in the bathroom and even listening to her urinate. The child, who is filming the woman who turns out to be her mother, then films a hamster as she poisons it with her mother's antidepressant medication, disseminating this act on social media and commenting on it in real time. The poisoning of the hamster serves as a precursor to the mother's overdose on antidepressants that puts her in a coma-an overdose, we are led to believe, that was orchestrated by Eve. The task of surveillance, it seems, has devolved to individual citizens as everyday life is mediatized by citizendocumentarians, participant-observers who comment on events as they unfold, or who live stream murder, whether it is the killing of a hamster or the slaughter of 50 worshippers in a mosque in New Zealand.

We also witness some sexually explicit email exchanges between lovers, Eve's father Thomas Laurent and a woman who is neither his ex-wife nor his current wife. Even though the intimacy of these exchanges is mediated by the inherent distancing effect of email, we, the film's viewers, are once again positioned as intruders in a place we do not belong, seeing things we should not see. We are even made to feel as though we are voyeurs, not in a private moment, but in a public setting, in a scene in which Anne's son Pierre humiliates himself 
when he performs a karaoke number in a crowded bar to the Sia song 'Chandelier'. Pierre's dance moves imitating the choreography of the viral music video are so awkward that they end in self-injury. Although Pierre is a willing performer, indeed a kind of exhibitionist, the performance is so excruciating, so exposing, that it makes viewers feel as if they are intruding on what should be a private moment.

Conversely, there are also times in the film when we are not close enough to the action to see or hear what is going on. In one scene, Pierre tries to visit the family of the man crushed by the collapsing wall and gets beaten up. The scene is shot from a distance, so we are not quite sure what is happening. Similarly, in another scene, we see Georges wheeling himself down a busy street in his wheelchair, but the camera is positioned across the road. When Georges talks to a group of men, we do not know what the subject of their conversation is. There is a tension in the film between seeing and not seeing, and, at least in this scene, between hearing and not hearing. Both these dynamics are manifestations of a more general tension between knowing and not knowing, which culminates in the film's final scene, when, as the sea engulfs the patriarch who wants to die and his grown children try to rescue him, we don't know if he ends up getting his wish. The film that does not permit us to know what we want to know is the same film that imposes knowledge on us that we do not want in its scenes that turn viewers into voyeurs.

Anne's relationship with Pierre seems to reflect a similar tension between excess and insufficiency, intimacy and distance, reflecting the dynamics of the 'double bind' identified by psychologist Gregory Bateson (1972). Pierre accuses Anne of being both too close (he pushes her away when she embraces him) and too distant (he says bitterly, 'There, she's back, my little mommy darling. Why don't you go home and get back to work?', implying that her work prevented her from being sufficiently attentive to him as a child). When Pierre extricates himself from his mother's embrace, it is not clear if he is being unduly resistant or if she is smothering him with affection. In an early exchange between Anne and Pierre at a family dinner, she rebukes him for drinking too much wine, and he bitterly denies that he drinks too much. Pierre's behaviour in this scene foreshadows his 'inappropriate' behaviour at the end of the film, when the 
simmering violence beneath the surface of his relationship with family (and his mother in particular) erupts into full view. In the film's climactic scene, Pierre bursts in to the party marking the engagement of Anne to a British lawyer at an elegant restaurant, decrying the plight of a group of African migrants. In order to quiet him, Anne bends Pierre's hand back with the clear intention (and effect) of injuring him, recalling the attack on Oleg the ape-man at the end of the fundraising dinner scene in The Square.

The motif of breached boundaries is established early in Happy End by the collapse of the wall on the family construction site. In the abstract, this image could suggest an anti-Trumpian breaking down of barriers between people, and even a Lennon-and-McCartneyesque plea to 'imagine there's no countries'. In this utopian scenario, the family that owns the construction company would be Builders without Borders, fostering goodwill between opposing groups. However, in this specific context, the fallen wall results in the death (or debilitating injury; it is not clear which) of a worker; in other words, there are non-utopian repercussions. These non-utopian repercussions, on the contrary, might be deemed topian, rooted in a particular place. That this place is Calais, stopping place for people hoping to immigrate to the UK, is no accident. With the final scene set during the engagement party of Anne and her English fiancé, we are invited to consider the impending union as an allegory of cross-Channel alliances within the European Union, in which case the disruption of the party celebrating this union might, in its sowing of division, be likened to Brexit.

The fact that Anne and her fiancé speak to one another in English is not questioned, and reflects the cultural imperialism of the language. In fact, a considerable amount of English is spoken in both films. In The Square, the use of English confirms its status as the lingua franca of the art world and, more broadly speaking, of institutions in a region such as Scandinavia that aspires to global status. In Haneke's film, the English title 'Happy End' evokes two somewhat different connotations, one taken from the world of children's stories and cheesy Hollywood blockbusters, and one from the domain of adult massage parlours. Yet, the phrase 'Happy End' is a bit off-kilter in English, which would normally take a gerund, i.e., 'happy ending'. The slight awkwardness of the phrase belies the fact that it has been appropriated by non-native speakers of 
English. It sounds almost right, but not quite. Like the 'assimilated' colonial subject who, in the eyes of the racist ideologue, will always retain a discernible residue of his or her essential difference, the phrase 'happy end' is legible as an indicator of 'accented cinema', perhaps not in the way that Hamid Naficy (2001) intended it, but in the sense of an utterance made by a linguistic outsider. In this case, the accent is a German one, as the phrase 'Happy End' is used and understood widely in German, which is the native language of Haneke, who is Austrian. This transnational layering of languages-English, via German, in a French-language film-is a specifically European one, involving the three most powerful countries in the EU (at least, before the prospect of Brexit plunged everything into chaos). It is significant that when we first see Anne's fiancé, he is watching a BBC news programme on television about a strike in Scotland. The prominence of the television broadcast in the scene (a trademark of Haneke's work) emphasizes the fact that the UK, the 'promised land' for the people who take up residence in what was called the Calais Jungle, is not without its tensions and internal conflicts, both in terms of class and regional-or even nationalidentity. Like Pierre at the parties he disrupts (or like the UK in relation to Europe), the inhabitants of the Calais Jungle are both in France and apart from France, just as the inhabitants of the housing estate in Stockholm where the 'black-haired' boy lives are alienated from within.

The engagement party scene is not the first time that Pierre has entered a crowded room to make inflammatory statements about immigrants. At Georges's $85^{\text {th }}$ birthday party, his grandson introduces domestic worker Jamila to the assembled guests as the family's 'Moroccan slave'. Almost as much as the things he says, it is the fact that he is stating the unstated, and the manner and context in which he states it, that shock. The outbursts in Happy End are all literally obscene-activities, thoughts, words that should have remained off-stage, but have not. Like the pivotal scene at the fundraising dinner in The Square, all revolve around parties, spaces of conviviality that are turned momentarily into theatres of incivility as invited guests/audience members look on in horror. In Happy End, Pierre's outrage about the treatment of immigrants is what disrupts the two celebrations. It is not clear, however, whether his outrage is genuinely directed at the status of immigrants, or if he is using this status as a pretext to shame his 
family and provoke their liberal guilt. In The Square, it is similarly unclear what the motivation is for the artist Oleg's out-of-bounds performance at the fundraising dinner. He incites, rather than expresses, outrage, prompting several men to beat him up. Both films appear to show 'outsiders' intruding into the sanctified space of civility, but in both films, these 'outsiders' are actually 'insiders'-Oleg is himself an artist hired by the museum to 'perform' at the fundraising dinner, while Pierre is the son of the person hosting the party. Pierre is taking to heart Stéphane Hessel's directive to 'Indignez-Vous', expressed in the title of his bestselling pamphlet, translated into English as Time for Outrage (Hessel 2011), and in which Hessel declares, 'To the young, I say: look around you, you will find things that make you justifiably angry-the treatment of immigrants, illegal aliens and Roma. You will see concrete situations that provoke you to act as a real citizen' (Hessel 2011: 18). According to the implied definition of a real citizen offered by Hessel, Pierre could indeed be said to be acting as one-not because it is only real citizens who act in this way, but because he has the privilege of acting in this way, the indulgence accorded to those who are already insiders, and have no apparent debt to repay. The blackhaired boy in The Square corners Christian, embarrasses him, makes him feel uncomfortable, but because he is not already an 'insider', there is only one thing that can happen to him. When Christian finally goes to apologise to him, he learns that he is gone.

These films can be seen as part of a body of work that Nathalie Rachlin and Rosemarie Scullion have called le cinéma indigné (2014: 5), which might be translated as 'Outrage Cinema'. Rachlin and Scullion define le cinéma indigné as 'a form of filmmaking that roundly condemns globalization ... by representing in stark cinematic terms the economic and social ills it has spawned" (2014: 5). They argue that the cinéma indigné 'serves a crucial function in artistically fathoming modes of opposition to the relentless self-seeking and productionist values championed in neoliberal thought' (Rachlin and Scullion 2014: 8). The Square and Happy End both give pride of place to the outrage generated by the neoliberal system of inequalities, but they do not offer alternatives to this system - though it could be argued that, as an affective medium, cinema's staging and indeed production of outrage is a fulfilment of its considerable but 
ultimately bounded potential. The expression of anger can be powerful, but such expressions are also often limited in their effects. For example, in The Square, when the head chef announces the lunch menu at a fundraising event in the museum, a large group of people begins descending the stairs before he has finished. The chef shouts (in an 'inappropriate' way) for people to stop, and then finishes reciting the menu. The crowd is shocked into silence when the chef shouts at them, but when he finishes his short speech, they continue on to their meal as though nothing has happened. Similarly, after Pierre disrupts his mother's engagement party, she invites the migrants to join everyone for lunch.

The question of hospitality in the respective societies depicted in these films is fundamental. The films ask, who is in a position to give, and who is in a position to receive? In the context of immigration, the host country 'receives' in the strictest linguistic sense of accepting people within its borders, but in a broader sense, the host country is constructed as a donor rather than a recipient. Immigrants, who are positioned as the recipients of the hospitality extended by the host country, do not, by definition, have the opportunity to return the favour, and they incur a debt that can never be repaid. In his landmark essay The Gift, sociologist Marcel Mauss (1966) described the potlatch ceremonies in which cultures of the Pacific Northwest displayed their wealth and power by destroying or giving away many of their possessions. Social and political rivals were expected to reciprocate at a later date, and until they exceeded the conspicuous consumption of the previous person, they lost face and were considered to be debtors. Social prestige is aligned with the power to give; debt is disempowering. Accordingly, as Mireille Rosello writes, “... if the guest is always the guest, if the host is always the host, something has probably gone very wrong. . . ironically, guests who are forced into the systematic position of the guest are often accused of parasitism, the host refusing to take responsibility for the historical position that deprives others of the pleasure and pride of taking their place" (Rosello 2001: 167). A system that positions incomers as parasites forecloses any possibility of reciprocity, thus reinforcing the acquisition of power and prestige by the party doing the giving. As Rosello further notes, 'Hospitality may be incompatible with a meticulous keeping of scores that forecloses future generosities and replaces them with precise debts' (Rosello 2001: 167). In Happy 
End, Anne is consumed with anxiety as long as she is indebted to the worker on whom the company's wall has fallen. Once she agrees, through the intervention of her lawyer (who also happens to be her fiancé) to pay the man's family a relatively small sum of money, she appears to feel that her debt, and her conscience, are clear, though the family is hardly better off. Similarly, when the family dog injures the child of her live-in domestic workers, Anne presents the child with a box of chocolates, and this gift appears to mark the cancelling of her debt.

In The Square, the question of debt is handled somewhat differently. When Christian goes to a 7-11 store that he uses as a channel to communicate with the person who has stolen his phone, he encounters a woman (who appears to be an immigrant) who asks him to buy her a sandwich, and insists that the sandwich should not contain onions. He agrees to purchase the sandwich for her, but when ordering it, neglects to specify that the onions should be omitted. The film does not linger on this moment or examine its repercussions, but it seems that not only is the woman withholding from Christian what he seems to want, which is gratitude and the acknowledgment of debt; Christian, in return, is not giving the woman exactly what she wants. He is extending hospitality of sorts, but it is a circumscribed hospitality; she is his guest, but she is not a thankful one. Although he gives, he gives only partially, and he gets no credit for his act; though she receives, she refuses to be in his debt. She seems to realize that ' $\mathrm{t}$ ] he price of hospitality is sometimes a form of imprisonment and exile whose realities the city of refuge will have to imagine and anticipate if it is to become less painful' (Rosello 2001: 165).

In both The Square and Happy End, strangers engage in social and economic transactions in which some debts are settled and (many) others are incurred. These debts suggest that the hospitality offered to immigrants comes at a price. The movement from 'there' to 'here' that constitutes immigration has as its endpoint a place of real or imagined refuge, a space defined by citizenship and (at least in principle) characterized by civility. The most fraught moments in these films show the intrusion of disruptors into these sanctified spaces. The stage for these disruptions is set in some cases by establishing the complicity of viewers (voyeurs) in breaking the bounds of intimacy. The discomfort of viewers 
is manipulated in these films as spaces of civility are breached by acts of incivility that express the vicarious outrage of 'insiders' on behalf of 'outsiders'. These disruptions bring hosts and guests together, serving ultimately, in a society characterized by infinite debt and finite hospitality, to underscore the distance between them.

Note: I wish to thank Kate Moffat for her comments on an early draft of this essay. 
WORKS CITED

Bateson, Gregory (1972), Steps to an Ecology of Mind: Collected Essays in Anthropology, Psychiatry, Evolution, and Epistemology, Chicago: University Of Chicago Press.

Beller, Jonathan (2012), The Cinematic Mode of Production: Attention Economy and the Society of the Spectacle, Hanover, NH: Dartmouth College Press.

Hessel, Stéphane (2011), 'Time for Outrage', The Nation, March 7/14.

Hessel, Stéphane and Edgar Morin (2012), The Path of Hope (trans. Antony Shugaar), New York: Other Press.

Mauss, Marcel (1966), The Gift: Forms and Functions of Exchange in Archaic Societies (trans Ian Cunnison), London: Cohen and West.

Moffat, Kate (2019), Crisis Politics in Contemporary Nordic Film Culture:

Representing Race and Ethnicity in a Transforming Europe, PhD Thesis submitted to the University of Stirling.

Naficy, Hamid (2001), An Accented Cinema: Exilic and Diasporic Filmmaking, Princeton: Princeton University Press.

Rachlin, Nathalie and Rosemarie Scullion (2014), 'Introduction: From Engagé to Indigné: French Cinema and the Crises of Globalization', SubStance, vol. 43, number 1 (Issue 133): 3-12.

Rosello, Mireille (2001), Postcolonial Hospitality: The Immigrant as Guest, Stanford University Press: Stanford, CA. 
Skodo, Admir (2018), 'Sweden: By Turns Welcoming and Restrictive in its Immigration Policy', in Migration Policy Institute (December 6),

(https://www.migrationpolicy.org/article/sweden-turns-welcoming-andrestrictive-its-immigration-policy; accessed 23 March 2019). 